\title{
SERTIFIKAT TANAH GANDA AKIBAT LEMAHNYA DATA BASE PERTANAHAN
}

Oleh :

\author{
Mudakir Iskandar Syah, SH., M.Hum
}

\begin{abstract}
Abstrak:
Sampai saat kini permasalahan sertifikat tanah ganda atau yang lebih dikenal dengan tanah sengketa masih tetap semarak, dan merupakan permasalahan lama yang belum terselesaikan. Penyumbang terjadinya sertifikat tanah ganda antara lain akibat data base pada Badan Pertanahan Nasional tidak valid, sehingga penyelesaian pembuatan sertifikat yang kedua dan seterusnya bisa dikatakan tidak selektif. Di pihak masyarakat masalah pertanahan khususnya masalah sertifikat tanah ganda belum sepenuhnya disadari, dan baru sadar setelah ada orang lain yang juga mempunyai sertifikat tanah atas tanah yang ia miliki. Karena ketidaktahuan masyarapat terhadap sertifikat tanah ganda, maka ia tidak bisa mengadakan upaya pencegahan. Tujuan dari penulisan ini untuk berusaha memberikan informasi, mengurangi, dan mencegah akan terjadinya sertifikat ganda atas tanah. Untuk pencegahannya, harus dilakukan secara serentak di semua lini yang ada kaitannya dengan data pertanahan. Pihak pemerintah sebagai penanggung jawab terhadap terjadinya sertifikat ganda harus mempunyai keberanian dan ketegasan dalam menegakkan hukum pertanahan. Disamping itu, pemerintah harus bisa memberikan informasi secara rutin tentang sertifikat agar masyarakat tahu semua kemungkinan yang menyebabkan terjadinya sertifikat ganda.
\end{abstract}

\section{PENDAHULUAN}

\section{A. Latar Belakang}

Tanah di Indonesia tetap menduduki ranking teratas dalam kaitannya sebagai penunjang kebutuhan hidup makluk hidup. Sesuai dengan norma hukum, semua kepemilikan terhadap barang baik barang bergerak maupun tidak bergerak (tanah) harus dilengkapi dengan alat bukti kepemilikan. Atau dengan kata lain, kepemilikan suatu benda yang tidak dilengkapi dengan alat bukti kepemilikan sama halnya tidak memiliki benda.

Kepemilkan kebendaan khususnya tanah, bisa dimiliki siapa saja khususnya untuk jenis tanah Hak Milik yang berhak harus Warga 
Negara Indonesia ( WNI), sedangkan untuk jenis lain bisa dimilik perorangan maupun kelembagaan baik kelembagaan yang pribumi maupun kelembagaan asing. Arti kelembagaan ini termasuk kelembagaan Negara Indonesia, karena Negara juga mempunyai hak untuk meiliki. Akan tetapi hak Negara ini lebih menitik beratkan kepada penguasaan dari pada kepememilkan. Arti menguasai hak Negara disini lebih mengarah pada pengaturan.

Dalam UUD 1945 Pasal 33 ayat (3) disebutkan Bumi, air dan kekayaan alam yang terkandung di dalamnya, yang penguasaannya ditugaskan kepada Negara Republik Indonesia, harus dipergunakan untuk sebesarbesarnya kemakmuran rakyat. ${ }^{1}$

Khusus kepemilikan terhadap tanah (benda tidak bergerak) sebagaimana dijelaskan dalam Pasal 2 ayat (1) Undang-undang Pokok Agraria: Bumi, air dan ruang angkasa, termasuk kekayaan alam yang terkandung di dalamnya, pada tingkatan yang tertinggi dikuasai oleh Negara.

Negara berhak menguasai atas tanah, sedangkan arti menguasai disini bukan berarti mengambil hak tanah perorangan, menguasai tanah tanpa prosedur, akan tetapi arti menguasai lebih menitikberatkan mengatur kepemilikan, Negara memang mempunyai hak menguasai dan memiliki, dalam arti memiliki ini untuk tanah tertentu yang memang statusnya menjadi tanah Negara. Kepemilikan tanah baik yang dimilki

${ }^{1}$.Republik Indonesia, UUD 1945 oleh perorangan, kelembagaan dan Negara semuanya harus dibuktikan dengan alat bukti kepemilikan, yang dinamakan sertifikat.

Untuk saat kini banyak tanah dengan status milik Negara yang diduduki oleh masyarakat tanpa dilengkapi administrasi yuridis. Biasanya sudah berjalan berpuluh puluh tahun lamanya, karena selama ini masyarakat menempati tanah tidak ada gugatan dari pihak lain, maka pihak yang menempati menganggap tanahnya merupakan kepemilikannya, walau tanpa ada surat selembarpun sebagai alat pembuktian. Untuk pihak Negara atau pemerintah sendiri tidak ada pencegahan awal sewaktu proses penempatan tanah Negara oleh masyarakat. Setelah sekian puluh tahun pemerintah akan menggunakan tanahnya tetapi sudah padat dengan pemukiman masyarakat.

Dibalik itu masih terdapat tanah pemerintah sendiri yang tidak dilengkapi dengan alat pembuktian, sehingga bisa dikatakan penguasaan tanah oleh pemerintah hanya secara defakto. Tanah yang demikian ini cepat atau lambat akan mengalami suatu permasalahan besar, sebagaimana yang telah terjadi di berbagai daerah di wilayah Indonesia.

Permasalahan tanah bisa menimpa kepada siapa saja, bisa terjadi pertentangan antara warga dengan warga, antara warga dengan lembaga, dan bahkan antara warga dengan pemerintah. Kalau melihat kondisi yang demikian, tanah bisa dikatakan sebagai sumber petaka. Bisa dikatakan sumber petaka apabila kepemilikannya tidak sesuai dengan prosedur dan tidak dilengkapi dengan alat bukti kepemilikan. 
Padahal kalau dipikirkan secara lebih jauh, untuk tanah yang telah mempunyai alat bukti yang dinamakan sertifikat saja tidak menjamin aman dalam kepemilikan tanahnya, dan bisa dibayangkan kalau kepemikan tanah tidak dilengkapi dengan sertifikat. Dikatakan bagi kepemilikan yang tanahnya telah dilengkapi dengan alat bukti sertifikat belum menjamin aman seratus persen, karena yang dinamakan alat bukti sertifikat merupakan alat bukti terkuat tetapi tidak mutlak, artinya sertifikat masih bisa disangkal keabsyahannya apabila ada pihak lain ada yang bisa mengadakan pembuktian terbalik.

Untuk saat ini ternyata ada banyak kasus berkaitan dengan satu bidang tanah, yang ternyata ada beberapa sertifikat (alat bukti), yang lebih dikenal di masyarakat adalah tanah sengketa. Kepemikilikan tanah kalau sudah diklasifikasikan sebagai tanah sengketa akan menjadi permasalahan yang ruwet, yang penyelesaiannya membutuhkan berbagai pendukung, mungkin dana waktu, dan sebagainya. Terlebih kalau penyelesainnya melalui badan peradilan akan membutuhkan waktu yang cukup panjang.

Terjadinya tanah sengketa akibat dari beberapa penyebab baik dari pihak masyarakat maupun pihak data base yang tidak valid di Badan Pertanahan Nasional (BPN). Karena muara kewenangan pembuatan sertifikat berada pada BPN. Data base yang tidak valid ini salah satu sebabnya adalah akibat tidak adanya masukan sumber data dari pihak pihak tertentu seperti dari pemilik tanah. Untuk saat kini Sebagian tanah di Indonesia tidak dilengkapi surat pembuktian otentik yang dikleluarkan dari pejabat yang berwenang, yang ada hanya sekedar surat non otentik yang dikeluarkan oleh pejabat yang tidak berwenang, seperti kitir, petok, ireda Ipeda, PBB dan sejenisnya.

\section{B. Identifikasi Masalah}

Asal mula terjadinya sertifikat ganda atau tanah sengketa akibat dari data base yang tidak valid. Hal ini mengakibatkan proses pembuatan sertifikat tanah seakan tidak terseleleksi. Dikatakan demikian karena pembuatan sertifikat yang kedua dan seterusnya dari sebidang tanah, seakan baru pembuatan pertama, karena akan dikomparatif dengan data base, dan ternyata datanya tidak ada. Dibalik itu pihak masyarakat sendiri belum sepenuhnya memahami akan sertifikat tanah. Sehingga permasalahan sertifikat ganda menjadi permasalahan yang sering muncul di masyrakat.

\section{Perumusan Masalah}

Tujuan dari penelitian ini untuk mengetahui dan mengurangi terjadinya sertifikat tanah ganda, dan kemudian menginformasikan kepada khalayak melalui berbagai media, sehingga masyarakat tahu akan arti dan resiko dari sertifikat tanah ganda dan sekaligus untuk berusaha melakukan pencegahan.

\section{Kegunaan}

1. Memberikan informasi tentang resiko sertifikat tanah ganda, dengan harapan masyarakat bisa melakukan pencegahan sejak dini. 
2. Agar data pertanahan pada Badan Pertananan Nasional di akurasikan sebaik mungkin agar bisa untuk pencegahan terhadap sertifkat ganda.

3. Agar pihak pemeroses sertifikat akan lebih teliti lagi dan bisa mencegah terjadi sertifikat ganda.

\section{E. Kerangka Pikir}

Permasalahan pertanahan termasuk di dalamnya permasalahan setifikat tanah, beberapa pandangan baik pandangan normatif maupun pandangan pakar antara lain :

1. Kerangka Teoritis, menurut pandangan pakar :

\section{S.J. Fockema Andreae:}

Merumuskan Agrarische Recht sebagai keseluruhan peraturanperaturan hukum mengenai usaha dan tanah pertanian, tersebar dalam berbagai bidang hukum (hukum perdata, hukum pemerintahan) yang disajikan sebagai satu kesatuan untuk keperluan studi tertentu. ${ }^{2}$

\section{A.P. Parlindungan :}

Untuk mengatasi permasalahan agraria ini harus tetap berpijak pada suatu teori tentang pandangan mengenai political will, pandangan megenai programming, pandangan mengenai pelaksanaan dan pelaksana, pandangan mengenai pengawasan, dan pandangan mengenai ketanahan nasional. ${ }^{3}$

2. Kerangka Konseptual, pandangan dari aspek normatif :

Permasalahan pertanahan yang termasuk di dalamnya masalah sertifikat tanah, yang menurut arti berdasarkan ketentuan antara lain :

a. Undang - undang Pokok Agraria Pasal 19 ayat (2) huruf c yang mengatakan : Pemberian surat-surat tanda bukti hak, yang berlaku sebagai alat pembuktian yang kuat. $^{4}$

b. Peraturan Pemerintah No. 24 Tahun 1997 Pasal 3 tentang Pendaftaran tanah, yang tujuannya :

1) untuk memberikan kepastian hukum dan perlindungan hukum kepada pemegang hak atas suatu bidang tanah, satuan rumah susun dan hak-hak lain yang terdaftar agar dengan mudah dapat membuktikan dirinya sebagai pemegang hak yang bersangkutan;

2) untuk menyediakan informasi kepada pihakpihak yang berkepentingan termasuk Pemerintah agar dengan mudah dapat memperoleh data yang diperlukan dalam

${ }^{3}$ A.P Parlindungan permohonan kepastian hukum Atas Hak Atas Tanah Menurut Peraturan Yang Berkaitan, (Makalah Seminar Fakultas Hukum USU, 1996) hlm. 2 ${ }^{4}$ Ibid 
mengadakan perbuatan hukum mengenai bidangbidang tanah dan satuansatuan rumah susun yang sudah terdaftar;

3) untuk terselenggaranya tertib administrasi pertanahan. $^{5}$

\section{METODE PENELITIAN}

Metode atau cara yang digunakan peneliti dalam rangka memperoleh data data yang akurat tentang obyek yang diteliti, maka penelitian meliputi:

1. Jenis Penelitian :

a. Deskriptif, dimana dalam penelitian ini peneliti berusaha memaparkan atau menguraikan data dan menyimpulkan, serta proses analisa data yang dalam lingkup sample.

b. Deduktif, berdasarkan teori atau konsep yang bersifat umum yang menjelaskan tentang seperangkat data, atau menunjukkan komparasi atau hubungan dengan seperangkat data yang lain.

c. Sumber data, Dalam pengambilan data penulis menggunakan :

1) Data primer, data sertifikat ganda yang telah menjadi sengketa di pengadilan;

2) Data skunder, dengan mengambil dari berbagai ketentuan hukum, media cetak, elektronik, buku dari berbagai judul dan karangan.
2. Metode Pengumupulan Data

Dalam pengumuplan data penulis menggunakan jenis :

a. Studi lapangan (fieled research), dengan mengambil contoh sertifikat ganda ke pengadilan.

b. Studi pustaka (library research), dengan mengambil dari berbagai judul buku dan karangan.

c. Wawancara (interview), mengadakan wawancara kepada pemegang sertifikat ganda

d. Pengamatan (observasi) terhadap peristiwa sertifikat tanah ganda dari masyarakat.

\section{PEMBAHASAN}

Dalam proses pembuatan sertifikat tanah akan didahului dengan pendafataran tanah. Pertanyaan selanjutnya adalah, apakah semua tanah yang ada di wilayah Indonesia sudah didaftarkan pada Kantor Badan Pertanahan? Sistem pendaftaran tanah yang diberlakukan dalam praktik di Indonesia menganut stelsel aktif, atinya apabila pemilik tanah aktif untuk melakukan pendafataran tanahnya, maka baru dipropses, dan sebaliknya kalau pemilik tanah tidak aktif untuk melakukan pendaftaran tanahnya maka tidak didaftar atau diproses oleh pemerintah.

Semakin banyak tanah yang tidak didaftarkan pada Kantor Badan Pertanahan Nasional, maka masalah tanah akan semakin banyak dan semrawut. Dikatakan demikian karena tanah yang tidak didaftarkan pada BPN tidak akan terdata dalam data base, sehingga bisa dikatakan tanahnya tidak ada kepastian hukum, berarti tidak ada jaminan kepastian hukum. 
Istilah sertifikat memang dalam Undang Undang Pokok Agaria (UUPA) tidak pernah disebut sertifikat tanah, akan tetapi dalam pasal 19 ayat (2) huruf $\mathrm{c}$ ada disebutkan surat tanda bukti hak. Dalam pengertian sehari-hari surat tanda bukti hak ini ditafsirkan sebagai sertifikat tanah. Surat tanda bukti hak atau sertifikat tanah itu dapat berfungsi menciptakan tertib hukum dan kepastian hukum pertanahan yang akan mempunyai dampak positif terhadap semua kegiatan makluk hidup khususnya manusia, terlebih kepada pemilik atau pemegang hak atas tanah.

Terbitnya sertifikat ganda akibat tidak validnya data base pada kantor BPN, apabila data yang ada telah akurat dan valid sudah pasti tidak mungkin bisa dikeluarkan sertifikat yang kedua dan seterusnya. Sertifikat ganda atas tanah adalah sertifikat yang diterbitkan oleh BPN, dan bisa terbitnya ini akibat adanya kesalahan pendataan pada tingkat awal. Data tingkat awal pertanahan di BPN tidak lengkap, begitu ada pemilik tanah mengajukan permohonan pembuatan sertifikat, seharusnya dikomparatif dengan data yang ada. Namun karena data yang awal tidak lengkap, maka tidak ada pembanding data, maka permohonan sertifikat dengan data yang dibawa oleh pemohon bisa dianggap lengkap, selanjutnya data pemohon dianggap lengkap sehingga proses pembuatan sertifikat bisa diterbitkan.

\section{Motif penggandaan sertipikat tanah}

1. Keawaman masyarakat mengenai arti dan manfaat dari sertifikat tanah itu sendiri, bahkan isi dan bentuk dari sertifikat itu tersendiri masyarakat belum mengenalnya.

2. Proses pembuatan sertifikat kedua dan seterusnya masih dianggap kurang selektif. Pihak Kantor Pemeroses lebih mengutamakan bukti administratiif, padahal perlu diketahui bahwa bukti administratif yang non otentik, banyak kelemahannya.

3. Proses pembuatan sertifikat selama ini masih dianggap sulit dan berbelit-belit, membutuhkan biaya cukup tinggi. Hal ini mengakibatkan keengganan masyarakat untuk mengurus sertifikat atas tanahnya.

4. Menghindari pajak BPHTB (Bea Perolehan Hak Atas Tanah dan Bangunan), Sesuai ketentuan PP 24 tahun 1997 bidang tanah yang perolehannya sebelum 24 Oktober tahun1997 diproses melalui pengakuan dan penegasan hak, sehingga tidak perlu dibuatkan Akta PPAT, dan dibebaskan dari pajak BPHTB dan SSB Pajak Penghasilan. Ketentuan mengenai Akta PPAT yang telah ditandatangani oleh PPAT harus dalam jangka waktu maksimal 7 hari harus sudah didaftarkan pada Kantor Pertanahan menyebabkan tanggal akta dibuat pada saat terjadi transaksi, dan sebelum PPAT menandatangani akta PPAT pajak BPHTB dan SSB Pajak Penghasilan sudah harus disetorkan kepada Negara melalui bank yang ditunjuk, sehingga mau tidak mau pemilik tanah tidak bisa menghindar dari kewajiban membayar pajak. Apabila sebidang tanah tersebut didaftarkan melalui pendaftaran pertama kali maka dengan bantuan saksi dan legalitas perangkat Desa/Kelurahan dapat dibuat seolaholah transaksi/perolehan tanahnya terjadi sebelum 24 Oktober 1997.

5. Adanya iktikad tidak baik dari pihak tertentu untuk menggandakan sertifikat tanah, dengan harapan bisa mendatangkan keuntungan secara 
ekonomi, diantaranya untuk jaminan hutang ke bank.

6. Apabila sertifikatnya hilang, pihak yang berhak atas sertipikat harus

a. bersumpah, bahwa sertifikatnya benar-benar telah hilang.

b. mengumumkan dimedia setempat sebanyak 2 kali dengan dua media yang berbeda,

c. mengumumkan di lembaran Negara Arsip Nasional selama 2 kali,

d. setelah 2 bulan tidak ada pihak yang berkeberatan, kemudian dibuatkan sertifikat pengganti.

Dan biaya pengumuman pada lembaran negara dan media setempat saat ini terbilang mahal. Apabila sertifikat yang dibuat melaui proses pendaftaran pertama kali jadi dan di kemudian hari sertifikat yang hilang tersebut ketemu dan muncul kembali, maka bisa dikatakan sertifikat tersebut double/ganda.

7. Biaya pendaftran sertipikat pertama kali lebih murah daripada Pendaftaran Peralihan Hak. Sebenarnya biaya yang masuk di Kantor Pertanahan lebih mahal biaya pendaftaran Sertifikat pertama kali akan tetapi pada kegiatan Pendaftaran Peralihan hak biaya pembuatan akta PPAT, pajak BPHTB, pajak SSB Pajak Penghasilan sangat mahal sehingga sangat memberatkan pemohon sertifikat, bisa dibayangkan apabila harga tanah mencapai 1 milyar, maka biaya untuk peralihan haknya bisa mencapai 100 juta rupiah. ${ }^{6}$

6

http://hanyarepost.blogspot.com/2011/07/ser tifikat-ganda.html

\section{Faktor-Faktor Terjadinya Sertifikat Ganda}

Sertifikat tanah atau sertifikat Hak Atas Tanah atau juga disebut Sertifikat Hak terdiri dari Salinan Buku Tanah dan Surat Ukur yang dijilid dalam 1 (satu) sampul. Sertifikat Tanah Memuat :

1. Data Fisik : menerangkan letak, batasbatas, luas, keterangan fisik tanah dan beban yang ada diatas tanah;

2. Data Yuridis : menerangkan jenis hak seperti hak milik, hak guna bangunan, hak guna usaha, hak pakai, Hak sewa, dan hak pengelolaan, dan nama pemegang hak.

Berdasarkan ketentuan pasal 31 dan pasal 32 Peraturan Pemerintah No. 24 Tahun 1997 serta penjelasan pasal demi pasal tersebut, sertifikat tanah di maksudkan agar pemegang hak dengan mudah membuktikan haknya. Sertifikat tanah merupakan tanda bukti hak atas tanah dan berlaku sebagai tanda pembuktian yang paling kuat.

\section{Proses Sertifikasi Tanah}

Sebelum proses yang mengarah kepada pembuatan sertifikat, proses yang paling awal harus didahului adanya transaksi tanah, termasuk transaksi tanah diataranya Jual beli, Hibah, wasiat, Pewarisan, Hadiah dan sebagainya. Dalam penelusuran sejarah tanah harus ada proses awal berupa transaksi, karena dengan adanya proses transaksi awal ini bisa diketahui dari mana asal mulanya tanah.

Proses kepemilikan tanah ini bisa saja pemberian dari pemerintah, seperti kaum transmigran mendapatkan jatah tanah dari Negara. Dengan adanya proses transaksi ini akan melahirkan akta, untuk tanah 
yang berasal dari jual beli dinamakan akta jual beli, untuk wakaf, dinamakan akta wakaf dan seterusnya.

Proses pembuatan akta bisa dilakukan di PPAT (Pejabat Pembuat Akta Tanah), Mungkin untuk di daerah tertentu pembuatan akta jual beli bisa pada pejabat pemerintah, seperti Camat, sedangkan untuk di Jakarta kewenangan Camat sebagai PPAT sudah tidak bisa lagi.

Untuk pembuatan akta karena wakaf atau pewarisan pembuatan pada Kantor Kementerian Agama Kabupaten/Kota. Biaya pembuata akta pada PPAT sangat bervariasi, dan memang tidak ada standar resmi, hanya kalau diambil rata-rata berkisar $1 \%$ dari jumlah harga, dan jumlah harga itu sendiri adalah : jumlah luas tanah $\mathrm{X}$ harge persatuan ukuran. Dengan demikian kalau sebidang tanah harga permeter Rp. 1.000.000 luas $100 \mathrm{M}$, maka biaya PPAT berkisar $1 \%$ $\mathrm{X} .1000 .000 \mathrm{X} 100=$ Rp. 1.000 .000 . Kemungkinan harga untuk PPAT ini masih harus ditambah lagi dengan biaya yang lain.

Standar harga tanah yang dipakai oleh PPAT pada umumnya adalah harga pasaran atau harga yang tertulis pada NJOP ( Nilai jaual Objek Pajak) yang berada pada SPPT Pajak Bumi dan Bangunan ( PBB). Sedangkan untuk pengurusan sertifikat tanah tidak cukup dengan pembayaran PPAT saja akan tetapi ada satu ketentuan lagi yang harus dibayar oleh pemegang hak atas tanah. yaitu Bea Perolehan Hak Atas Tanah dan Banguan (BPHATB), yang besarnya $5 \%$ dari jumlah harga. Dengan demikian pengeluaran resmi calon pembuatan sertifikat tanah sampai dengan pengusulan pembuatan sertifikat minimal $1 \%+5 \%$ $=6 \% \mathrm{X}$ jumlah harga.
Setelah membayar $6 \%$ baru bisa mendaftarakan pada kantor Badan Pertanahan Nasional. Biaya untuk di BPN jelas masih ada biaya resmi, bahkan mungkin ditambah biaya tidak resmi. Biaya yang berjumlah $6 \%$ ini berarti biaya minimal, yang kalau dijumlah kesemuanya diperkirakan bisa mencapai $10 \%$ dari jumlah harga tanah. Proses pembuatan sertifikat di BPN ini diawali proses pendaftaran tanah dengan proses pengukuran, pemetaan, pembukuan dan selanjutnya, yang akirnya setelah semua proses terlalui, akan terbit yang dinamakan sertifikat tanah.

Apabila telah terpenuhi syarat tersebut kemudian proses Pendafataran tanah, yang diatur dengan PP No. 24 Tahun 1997, yang tujuannya dari pendaftaran tanah itu sendiri untuk mendata secara yuridis dengan harapan setiap kepemilikan terhadap tanah mempunyai daya laku yang akurat, dan apabila terjadi pengalihan hak dari satu pihak kepada pihak lain datanya tersusun secara kronologis.

Pendaftaran tanah menurut UUPA No. 5 Tahun 1960 Pasal 19:

a. Untuk menjamin kepastian hukum oleh pemerintah diadakan pendaftaran tanah, menurut ketentuan-ketentuan yang diatur dengan ketentuan pemerintah.

b. Pendaftaran tanah meliputi :

1) Pengukuran, perpetaan dan pembukuan tanah

2) Pendaftaran hak-hak tanah dan peralihan hak

3) Pemberian surat tanda bukti hak yang berlaku sebagai alat pembuktian yang kuat

c. Pendaftaran tanah diselenggarakan dengan mengingat keadaan Negara dan 
masyarakat menurut pertimbangan Menteri Agraria. $^{7}$

\section{Tujuan dari pendaftaran tanah :}

a. Untuk memberikan kepastian hukum sekaligus perlindungan hukum kepada setiap kepemilikan hak atas tanah. Bagi tanah yang telah dilakukan pendaftaran mempunyai kekuatan hukum yang lebih dari pada tanah yang tidak dilakukan pendaftaran. Hukum melindungi terhadap tanah yang telah didaftarkan pada BPN, dengan catatan selama proses dan syarat yuridis adminitratif waktu proses pendaftaran telah memenuhi persyaratan.

b. Untuk menyediakan informasi pertanahan kepada piha-pihak tertentu termasuk pihak yang berkepentingan baik yang berkepentingan pemerintah itu sendiri atau lembaga swasta agar mendapatkan kemudahan dalam memperoleh data tanah bila akan memerlukan lahan;

c. Untuk menyelenggarakan tertib administrasi dibidang pertanahan.

\section{Alat bukti atas tanah :}

a. Sertifikat, merupakan alat bukti yang paling kuat, tetapi tidak mutlak terhadap kepemilikan suatu tanah dan surat yang disebut sertifikat ini disebut alat bukti yang kuat tetapi tidak mutlak artinya alat bukti yang terkuat diantara alat bukti uang lainnya, dikatakan tidak mutlak karena alat bukti sertifikat ini masih bisa dianggap tidak syah, apabila ada pihak lain yang bisa membuktikan kebalikannya, Setelah diadu kekuatan dalam pembuktianya, maka bagi pemegang alat bukti yang paling

7 Indonesia, Undang-Undang Pokok Agraria, UU No. 5 Tahun 1960 lengkap serta cara peralihan hak dan pembuatan alat buktinya melalui prosedur yang semestinya, yang akan menang dalam kepemilikan dan sebaliknya bagi alat bukti atau sertifikat yang pembuatannya tidak prosedural yang dianggap kalah dalam pembuktian.

b. Akta merupakan suatu alat bukti kepemilikan suatu benda, untuk tanah akta ini berupa akta peralihan hak termasuk akta jual beli, waris, hibah dan lain sebagainya. Akta merupakan alat yang melalui proses Pejabat Pembuat Akta Tanah atau pejabat lain yang mempunyai wewenang (dahulu Camat bisa bertindak sebagai Pejabat Pembuat Akta Tanah). Alat bukti ini merupakan alat terhadap kepemilikan tanah dan menjelaskan sejara peralihan hak atas tanah termasuk akta jual beli, akta waris, akta hibah dan sebagainya. Secara yuridis alat bukti ini juga sudah mempunyai kekuatan hukum, akan tetapi tidak sekuat alat bukti yang dinamakan sertifikat.

c. Alat bukti yang lain, seperti girik, petok dan sejenisnya, alat bukti semacam ini termasuk alat bukti yang lemah, namun di Indonesia terutama di daerah alat bukti semacam ini masih banyak diketemukan dan dimiliki para pemilik tanah. Sedangkan surat PBB (Pajak Bumi dan Bangunan), Ipeda (Iuran Pembangunan Daerah), Ireda (Iuran Rehabilitas Daerah) dan sejenisnya bukan merupakan alat bukti kepemilikan tanah akan tetapi sebagai bukti pemilik benda dalam kaitan berkewajiban membayar pajak. ${ }^{8}$

8 Mudakir Iskandar Syah, SH.MH, Pembebasan Tanah Untuk Pembangunan Kepentingan Umum (Jakarta : Jala Permata Aksara, 2010) hlm. 37 
Alat bukti tanah dilihat secara aspek yuridis kepemilikan, bahwa kepemilikan yang disertai dengan alat bukti administratif dan yuridis, bisa dikatakan kepemilikan yang kuat, dan sebaliknya kepemilikan terhadap suatu benda yang tidak disertai alat bukti yuridis administratif maka kebendaan itu dianggap tidak pernah ada, walaupun secara defakto kebendaan memang ada dan dalam penguasaan pemilik. Kepemilikan kebendaan khususnya tanah, yang hanya didasari secara defakto, memang selama tidak ada pihak lain yang mengakui atau mengusik, dianggapnya aman- aman saja. Akan tetapi dilihat dari aspek hukum, kepemilikan kebendaan itu tetap dianggap tidak pernah ada. Kalau ada orang lain yang mengakui dan dilengkapi dengan alat bukti yuridis, maka orang lain itulah yang berhak secara yuridis. Kesimpulannya, kepemilikan kebendaan harus ditunjang dengan alat bukti secara defakto, dan secara yuridis adminitratif.

Kepemilikan pertanahan harus diawali prinsip dasar dalam pendaftaran tanah, walau bukti kepemilikan surat tanah sudah ada, seringkali masih terdapat permasalahan yang lain seperti luas tanah juga tidak akurat, artinya luas tanah yang tertulis dalam surat tanah/sertifikat dengan fisik tanah dilapangan tidak sinkron, sehingga menimbulkan permasalahan yang berkepanjangan atau tanah yang berdekatan letaknya sering terjadi tumpang tindih kepemilikannya.

Permasalahan serfikat tanah sebetulnya tidak hanya yang menyangkut sertifikat ganda saja, akan tetapi masih banyak permasalahan lain, seperti luas, batas dan sebagainya, atau tumpang tindih data. Walau masalah ini kalau jadi sengketa di pengadilan, dan seandainya dikalahkan, maka tidak mengakibatkan hilangnya fisik tanah. Namun cukup menyita energi yang tidak sedikit.

\section{Penyebab Terjadinya Sertifikat Ganda :}

a. Tidak adanya basis data yang valid mengenai tanah secara detail di Kantor Badan Pertanahan Nasional. Sehingga apabila tanah tersebut didaftarkan lagi maka dapat diketahui tanah tersebut sudah bersertipikat.

b. Unsur kesengajaan pemilik tanah untuk mendaftarkan kembali sertifikat Hal ini terjadi karena pembuatan sertifikat baru lebih mudah dan lebih murah daripada melakukan peralihan hak atas tanah. Sedangkan untuk peralihan hak atas tanah harus melalui Akta PPAT, PPAT dengan Bea Perolehan Hak Atas Tanah dan Bangunan (BPHTB) yang besarnya 5 $\%$ dari Nilai Jual Obyek Pajak/harga transaksi Jual Beli dikurangi Nilai Jual Obyek Tidak Kena Pajak. Sedangkan SSB Pajak Penghasilan besarnya $5 \%$ dari Nilai Jual Obyek Pajak/harga transaksi Jual Beli. Dari jumlah pengeluaran tersebut harus ditambah lagi bea pembuatan akta PPAT, sedangkan untuk mendapatkan kredit dari bank yang lain dibuatkan sertifikat baru. Sehingga satu bidang tanah yang dijadikan agunan kepada beberapa bank dengan bukti sertifikat yang berbeda tetapi bidang tanahnya sama.

c. Keteledoran Badan Pertanahan Nasional dalam pelaksanaan bywerken Peta Pendaftaran. Dimana setiap pelaksanakan pengukuran bidang tanah harus diikatkan dengan titik dasar teknik yang ada dan penempatan gambar bidang tanah harus digambar pada posisi yang tepat pada peta pendaftaran tanah Seringkali karena kurang teliti terjadi salah penempatan 
gambar ataupun lupa tidak digambar pada Peta Pendaftaran.

d. Tidak cukup tersedianya peta pendaftaran tanah yang meliputi seluruh wilayah kabupaten, dan banyak gambar bidang tanah yang tidak dipetakan. Untuk saat ini tersedia Peta Base Map dengan aplikasi Land Office Computerism (LOC) (kantor pertanahan) dan fasilitas Autocad Map yang bisa digunakan untuk bywerken Peta, akan tetapi informasi yang disajikan masih kurang mendukung. ${ }^{9}$

\section{Dampak Dari Sertifikat Ganda}

a. Terjadi sengketa hak atas tanah, dan penyelesaiannya sering terjadi melalui pengadilan, sedangkan penyelesaian dengan cara musyawarah sangat kecil kemungkinannya., karena masingmasing pihak akan tetap mempertahankan kebenaran bukti masing-masing.

b. Terjadinya keresahan masyarakat, terlebih bagi masyarakat pencari tanah akan selalu dihinggapi perasaan kekawatiran. Takut tanah yang akan dibeli ternyata tanah sengketa.

c. Bagi para pihak yang bersengketa atas tanahnya bisa timbul anarkis dengan main hakim sendiri, yang berdampak timbulnya ketegangan di masyrakat.

d. Menimbulkan kesan tidak baik terhadap lembaga BPN sebagai lembaga pemeroses sertifikat tanah

e. Menimbulkan ketidak percayaan masyarakat terhadap kepastian hukum hak atas tanah. Seharusnya sertifikat hak atas tanah merupakan tanda bukti pemilikan hak atas tanah yang kuat,

${ }^{9}$ http://hanyarepost.blogspot.com/20 11/07/sertifikat-ganda.html akan tetapi tidak bisa disebut kuat karena adanya sertifikat kedua dan seterusnya dari obyek tanahnya yang sama.

Upaya penyelesaian Sertifikat Ganda Saat ini :

1. Kantor Pertanahan dalam menangani sengketa sertipikat ganda bisa dengan cara mediasi. Akan tetapi kalau dengan cara mediasi tidak mendapatkan kesepakatan maka pasti melalui proses pengadilan.

2. Masalah lain, untuk mengelak dari tuntutan : Pada saat penerbitan sertipikat sebelumnya telah melalui lembaga pengumuman selama 2 bulan di Desa/Kelurahan maupun di Kecamatan seharusnya pihak yang berkeberatan menggunakan waktu tersebut untuk mengajukan keberatan atas penerbitan sertipikat, Kelemahannya diumumkan di masmedia, ternyata tidak semua orang membaca dan memperhatikan pengumuman.

3. Selain itu setelah terbit sertifikat pemilik tanah dan pemerintah desa diberi surat untuk mengambil sertifikat yang sudah jadi di Kantor Pertanahan. $\mathrm{Hal}$ itu juga digunakan untuk mengelak dari kesalahan bahwa semestinya Pemerintah Desa mencatat bidang tanah tersebut telah bersertifikat, padahal undangan seringkali tidak dikirim ataupun tidak sampai pada pemohon.

\section{KESIMPULAN}

1. Sertifikat ganda bisa terjadi karena akibat dari kelalaian atau kurang kehati - hatian dari pemeroses pembuatan sertifikat, yang semula bisa diawali 
ketidak validnya data pemohon sertifikat, namun karena sesuatu hal tetap juga diloloskan, sehingga terbitlah sertifikat yang kedua dan seterusnya.

2. Adanya data yang tidak valid di Badan Pertanahan Nasional, Ketidak validan ini bisa juga disebabkan karena tidak adanya masukan data dari para pemilk tanah, dan ditambah lagi pihak pengelola data tidak proaktif mencari data pada sumber data, atau dengan kata lain antara pengelola data dan sumber data sama-sama tidak aktif, atau saling menunggu.

3. Adanya niat jahad dari pihak tertentu untuk sengaja membuat sertifikat tandingan, dengan tujuan bisa dimanfaatkan untuk keuntungan pribadi dari aspek ekonomi.

4. Adanya kesengajaan dari pihak tertentu untuk membuat sertifikat tanah yang kedua dan seterusnya dengan tujuan untuk mendapatkan keuntungan

5. Belum adanya sistem informasi pertanahan (SIMTA), pada kantror Pertanahan, sehingga tidak ada buku direktori/petunjuk dalam penelusuran tanah.

\section{SARAN}

1. Pihak Badan Pertanahan Nasional harus meningkatkan kevalidan data pertanahan dengan berbagai cara, sehingga tidak terjadi data tumpang tindih, data semu yang bisa memberi peluang terbitnya sertifikat tanah kedua dan seterusnya.

2. Menciptakan sistem kontrol yang ketat terhadap semua permintaan pembuatan sertifikat, salah satunya dengan on line sistem data dengan berbagai kantor yang ada kaitanya dengan data pertanahan.
3. Pemerintah harus segera memulai menciptakan sistem infromasi pertanahan (SIMTA). Agar memudahkan masyrakat dalam menelusuri tanah, dan seklaigus mencecegah terjadinya sertifikat ganda. Kalau SIMTA ini sudah terciptakan, semua pihak akan bisa mengakses penelusuran tanah dari berbagai kantor, seperti di kantor kelurahan, atau kantor- kantor tertetntu.

4. Badan Pertanan harus berani memberikan punishmen kepada pihak yang memncoba mamalsu data atau telah memalsu data, yang bisa member peluang terjadinya sertifikat yang lebih dari satu dari satu bidang tanah. Semua ketentuan tidak akan berjalan dengan mulus bisa punishment tidak diberlakukan.

5. Badan Pertanahan Nasional harus memberikan informasi, peyuluhan kepada masyarakat, tentang alat bukti hak atas tanah, khususnya sertifikat tanah ganda. Perlu diketahhui bahwa sebagian besar masyrakat masih sangat awam tentang pengetahuan sertifikat tanah.

6. Pemerosesan permohonan sertifikat bisa dilakukan secara on line, dengan harapan tujuan proses dari pembuatan sertifikat itu sendiri bisa cepat, tepat, dan biaya ringan. Dan untuk control, para pemohonan yang yang telah mengisi data on line harus menyerahkan data dokumen asli kepada kantor pemeroses 


\section{DAFTAR PUSTAKA}

1. Badan Pertanahan Nasional, HImpunan Peraturan Perundangundangan Pertanahan Yang Berkaitan Dengan Penetapan hak Atas Tanah Dan Pendaftaran Tanah Jilid III, Pusat Hukum Dan Hubungan Masyarakat, Tahun 2007

2. ---, HImpunan Peraturan Perundang-undangan Pertanahan Yang Berkaitan Dengan Reforma Agraria, Pusat Hukum Dan Hubungan Masyarakat SJDI Hukum, Tahun 2011

3. --- Peraturan Meneter NegaraAgraria/Kepala Badan Pertanahan Nasional Nomor 2 Tahun 1993 tetang Tata Cara Memperoleh Izin Lokasi Dan Hak Atas Tanah Bagi Perusahaan Dalam Rangka Penananman Modal.

4. Bahan Conferensi Internasional tentang conperence Regulatory Reform on Indonesia Land Laws For People"s Welfaper, diselenggarakan Universitas Indonesia kerjasama Badan Pertanahan Nasional Republik Indonesia, tanggal 11 Desember 2012. di Jakarta.

5. Harsono, Budi, Hukum Agraria Indonesia, Sejarah Pembentukan UUPA, Isi Dan Pelaksanaanya, Jilid I, Jakarta: Djambatan 1999.

6. Iskandar Syah, Mudakir, Pembebasan Tanah Untuk Pembangunan Kepentingan Umum, Upaya hukum Masyarakat Yang Terkena Pembebasan Dan Pencabutan Hak, Jakarta : Jala Permata, 2010

7. Mulyadi, Kartini, dan Wijaya Gunawan, Hak Hak Atas Tanah, Jakarta: Prenada Media 2004.
8. Republik Indnesia, Undang undang Nomor 5 Tahun 1960, Tentang Peraturan Dasar Pokok Pokok Agraria.

9. - - Peraturan Pemerintah Nomor 40 Tahun 1996 tetang Hak Guna

i. Usaha, Hak Guna Bangunan Dan hak Pakai Atas Tanah.

10. ------ Undang Undang Nomor 20 Tahun 1961 tentang Pencabutan Hak Atas Tanah Dan Benda Benda Yang Ada di Atasnya.

11. Undang Undang Nomor 24 Tahun 1992 Tentang Penataan Ruang

12. , Peraturan Pemerintah Nomor 8 Tahun 1953 Tentang Penguasaan Tanah Negara. 